\title{
ポリグリセリン脂肪酸エステルの可溶化・乳化特性 Emulsification and solubilization characteristics of Polyglycerol Fatty Acid Esters
}

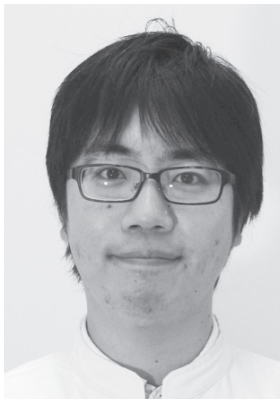

\author{
樋口 智則 \\ 太陽化学株式会社 \\ インターフェイスソリューション事業部 \\ 干 510-0844 \\ 三重県四日市市宝町 1-3 \\ Tomonori HIGUCHI \\ INTERFACE SOLUTION DIVISION, \\ TAIYO KAGAKU CO., LTD \\ 1-3 Takaramachi, Yokkaichi, Mie 510-844, Japan
}

論文要旨：界面活性剤を用いた可溶化・乳化は様々な分野で用いられているが，目的とする可溶化物や乳 化物を得る為には，使用する界面活性郕の種類と添加量の選択や調製方法が重要となる。本稿では界面活性 剂として食品や化粧品用途で幅広く利用されている非イオン界面活性剂「ポリグリセリン脂肪酸エステル (PGFE)」の可溶化・乳化特性について解説した。

PGFE は分子構造の設計自由度が高く，広範囲な HLB の分子設計が可能である。また，水和力が強い為 に温度や塩，多価アルコール等の共存物質の影響を受けにくい。さらに，水中でも油中でも臨界ミセル濃度 が低く疎媒性を有する界面活性剤であるという事が知れられており，興味深い特性を持つ。このPGFEの 構造と特徵を活かした応用例について最近の研究動向を交えつつ述べた。

\begin{abstract}
Although solubilizing and emulsifying technologies using surfactants are generally used in various industries by recognizing their high practicalities, not only to determine the right types and dosage of surfactants, but to select optimizing preparation methods should be a prerequisite for a desirable target formulation. This review explains emulsifying and solubilizing properties of non-ionic surfactant "Polyglycerol Fatty Acid Esters (PGFE)", which has been widely used in countless food and cosmetic applications.

With higher flexibility in designing molecular structures, diverse molecules of PGFE can be designed and built while covering a wide range of HLB. In addition, PGFE is less affected by temperature or coexisting ingredients such as salt and polyols on the strength of its powerful hydration force. It is also well-known for having an intriguing property, which can effectively form self-assembly owing to its low CMC (Critical Micelle Concentration) level both in water and oil. In this review, we introduce application guidance with the latest research trends while focusing on the structural characteristic and specific properties of PGFE.
\end{abstract}

Key words: polyglycerol fatty acid esters, solubilization, emulsification, cmc, self-assembly

\section{1 はじめに}

\section{界面活性剂を用いた乳化・可溶化の技術は実用性が高}

く，様々な分野で用いられているが，目的とする可溶化 物や乳化物を得るためには使用する界面活性剤の種類と その使用方法の選択が重要である。界面活性剤は, アニ オン界面活性剂, カチオン界面活性剂, 両性界面活性剂,

連絡者：樋口 智則

E-mail : thiguchi@taiyokagaku.co.jp
非イオン界面活性剂など様々な種類があるが，本稿では 非イオン界面活性剤であるポリグリセリン脂肪酸エステ ル（PGFE）の乳化・可溶化特性及びその応用例につい て紹介する。

PGFE は，親水基がポリグリセリン，疎水基が脂肪酸 である多価アルコール系の非イオン界面活性剂で，日本 の食品添加物としても使用されている安全性の高い界面 活性剂である。ポリグリセリンの重合度, 脂肪酸鎖長, そしてエステル化度を変えることにより親水性－親油性 
バランス（HLB）を自由に調整できるため，可溶化・ 乳化といった界面活性能だけでなく様々な機能を有して おり, 油脂の結晶コントロールや澱粉・蛋白の改質など の食品改質剤として幅広く利用されている ${ }^{1)}$ 。また，安 全性や皮膚への低刺激性だけでなく, 優れた洗浄力を有 することから， シャンプー ${ }^{2,3)}$ やクレンジング ${ }^{4-6)}$ など にも利用されており，更に環境や安全志向の高まりも あって幅広い分野でその利用が増加する傾向にある。

PGFEは, 水和力が強い為に温度や塩, 多価アルコー ル等の共存物質の影響を受けにくいという特性があり, 様々な剂型に配合しやすい。また，水及び油何れの系に おいても臨界ミセル濃度が低く疎媒性を有する界面活性 剂であり，自己組織体を形成しやすい事が知られてい る。本稿では, PGFEのユニークな可溶化特性や, 自己 組織体の形成しやすさを利用した乳化方法, 調製した可 溶化・乳化物の安定性の高さ等, PGFEの特徵を活かし た応用例について, 最近の研究動向を交えつつ紹介する。

\section{2 ポリグリセリン脂肪酸エステルの構造}

親水部となるポリグリセリンには，様々な製造方法が あるが，一般的にはグリセリンを不活性ガス中のアルカ リ触媒存在下 $150 \sim 300^{\circ} \mathrm{C}$ で反応する脱水重合法により 得ることができる ${ }^{7)}$ 。ポリグリセリンには重合度分布が あり，高重合度のものでは，直鎖や分岐状のものだけで なく分子内で脱水縮合した環状体も多量に含まれるが (Fig. 1A)，通常の脱水縮合とは異なる製造方法により， 極端に環状体の含有量を少なくしたポリグリセリンや, 特定の重合度を主成分とした高純度なポリグリセリンを 製造出来る事が知られている ${ }^{7)}$ 。PGFE は, 脂肪酸種や エステル化度，ポリグリセリンの重合度だけではなく， その骨格も選択できるため，更に分子構造の設計自由度 が高い界面活性剤であると言える（Fig. 1B）。

\section{3 ポリグリセリン脂肪酸エステルを用いた可溶化特性}

可溶化とは, 水（または油）中に形成する界面活性剂 の自己組織体へ油(または水)を溶解させた現象である。 熱力学的に安定な一液相で外観は透明であり, 可溶化量 は組成・温度などの条件により決まる。特に多量に可溶 化されたものはマイクロエマルションと呼ばれている。

球状ミセルへの可溶化は, 被可溶化物の極性により, 可溶化位置が異なる事が知られており ${ }^{8)}$, 例えば, 炭化 水素などの非極性物質はミセルのコア部分に可溶化さ れ，コアシェル型という。一方，長鎖アルコールなどの 極性基を持つ物質は，その極性基を界面活性剂の親水部 側に, 疎水基をミセルの内部に向けて, 界面活性剂分子 間に可溶化され，パリセード型という。また，極性の強
A

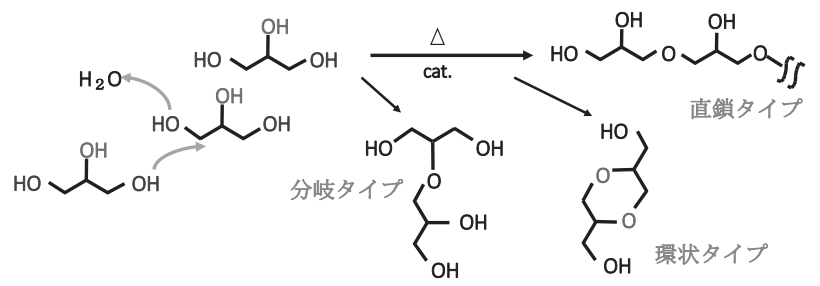

B

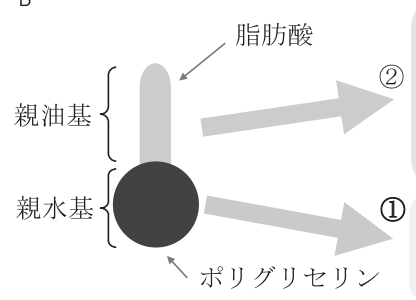

(3)

(1)ポリグリセリンの重合度

(2)脂肪酸の種類 (炭素数、飽和、不飽和、分岐鎖脂肪酸など) (3)エステル化率

Fig. 1 ポリグリセリン脂肪酸エステルの構造

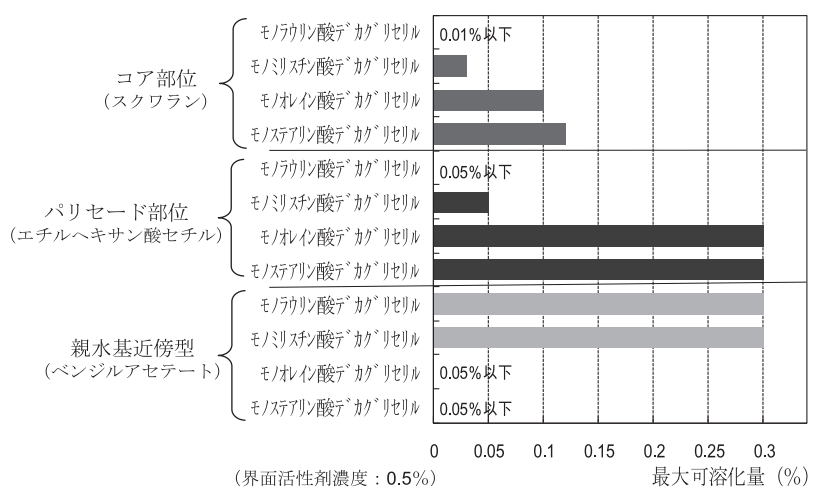

Fig. 2 ポリグリセリン脂肪酸エステルの可溶化特性

い有機化合物などはミセル親水部表面に吸着するように 可溶化される。ここで，親水性を高める為に，ポリグリ セリン骨格において，環状物が少なくなるよう合成して 調製したPGFE（界面活性剤濃度 $0.5 \%$ ）の可溶化につ いて紹介する。スクワラン（コア部位へ可溶化），エチ ルヘキサン酸セチル (パリセード部位へ可溶化), ベン ジルアセテート（親水基近傍へ可溶化）の 3 種類の被可 溶化物質の可溶化特性を検討した結果, スクワランの場 合, アルキル鎖の長い $\mathrm{C} 18$ のデカグリセリンエステル で最大可溶化量が大きい傾向にあった（Fig. 2)。これは， アルキル鎖長が長いほど, 可溶化部位であるコア部体積 が大きくなるためと考えられる。次に,ベンジルアセテー 卜の場合，アルキル鎖長は $\mathrm{C} 12,14$ のデカグリセリン エステルで最大可溶化量が大きい傾向にあった。親水基 近傍に可溶化されるため, 親水部の構造が影響している と推測される。エチルヘキサン酸セチルの場合は, コア 部位可溶化型と同様にアルキル鎖長が長い C18 のデカ 
グリセリンエステルで最大可溶化量が大きい結果となっ た。また，同じアルキル鎖長のデカグリセリンエステル において，分子内で脱水縮合した環状体の多いPGFE は可溶化量が小さい結果となり，親水基の構造も大きな 影響がある事を確認した。

次に, PGFE を用いた可溶化で興味深い効果について 紹介する。化粧品などで使用される可溶化型（例えば化 粧水など）は，香料や保湿目的で配合される油分などの 非水溶性成分を界面活性剂などで可溶化させており，こ れらにはPOE系非イオン界面活性剤が使用される事が 多いが，パラベン類などの防腐成分をミセル中に封じ込 め, 防腐力を損なわれることが知られている ${ }^{9)}$ 。しかし, PGFEとしては，アルキル鎖長が C14のデカグリセリ ンエステルを用いた可溶化系で，防腐力を損ないにくい といった傾向が確認されている（Table 1)。これは親水 基近傍型の可溶化モデルとなり，防腐成分をミセルの奥 に封じ込める事が無いためではないかと考えられる。

\section{$3 \cdot 1$ 可溶化物の安定性}

界面活性剂の性質は温度や共存成分によって変化する ため，ある条件（組成や温度など）で可溶化や乳化系が 破壊されることがある。そこで，PGFEを用いた可溶化 系において，塩及び熱による影響を調べた（Fig. 3）。結 果，スクワランの可溶化系において，PGFEを用いた可 溶化水溶液はいずれも良好な状態を保っていたが，POE 系界面活性剂では，硫酸 $\mathrm{Mg}$ の添加や加温（50²）する と, 白濁して可溶化不良が起こった。これは, PGFEに よる可溶化系が, POE 系非イオン界面活性剤と比べて 塩や温度などの影響を受けにくく，耐塩，耐熱性のある

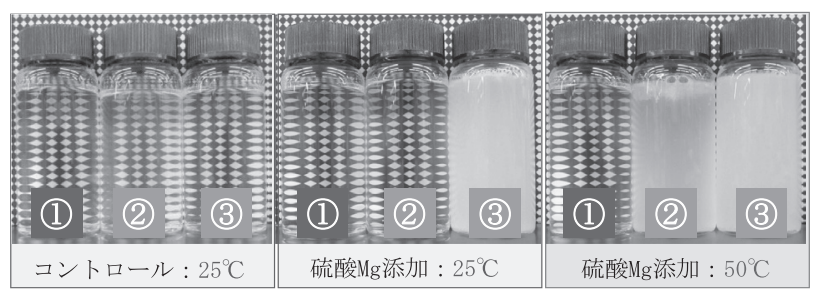

(1) モノミリスチン酸デカグリセリル (2) ポリソルベート 80 (3) PEG-60水添ヒマシ油

ル ; 界面活性剤 $0.5 \%$ 、スクワラン $0.02 \%$ 硫酸Mg添加 ; 界面活性剂 $0.5 \%$ 、スクワラン $0.02 \%$ 、硫酸Mg $8.0 \%$

Fig. 3 可溶化水溶液の耐塩・耐熱性

事を示している。これら違いについては, 界面活性剤の 量点現象で説明する事が出来る。

一般に POE 系非イオン界面活性剂は温度の上昇とと もに脱水和が起こり，親水性から親油性へと変化する。 これは, $\mathrm{POE}$ 鎖と水の水素結合が切れることに加え， $\mathrm{POE}$ 鎖のコンフォメーションが変化し，親水鎖全体の 極性が減少するためと考えられている ${ }^{10)}$ 。温度上昇に よる親水性の減少で起こる典型的な例が曇点現象であ る。PGFEにも量点現象は存在するが, その挙動は POE 系非イオン界面活性剤とは大きく異なる事が知ら れている。POE 系非イオン界面活性剤では HLB の増加 に伴い量点は単調に上昇するが, PGFEでは, HLBの わずかな変化で曇点は急激に上昇する。従って親水性の PGFE では，一般的に量点現象は観察されない。これは PGFE の溶存状態に対する温度の影響が少ないことを示 している ${ }^{11)}$

量点現象は，温度だけではなく塩や多価アルコールな どの共存成分によっても引き起こされる事が知られてい

Table 1 プロピルパラベンを可溶化した系での防腐効力試験

\begin{tabular}{|c|c|c|c|c|}
\hline $\begin{array}{l}\text { プロピルパラベン }(0.1 \%) \\
\text { +モノミリスチン酸デカグリセリル (1\%) }\end{array}$ & 初期值 & 7 日目 & 14 日目 & 21 日目 \\
\hline 大腸菌 & $6.7 \times 10^{7}$ & $<10$ & $<10$ & $<10$ \\
\hline 黄色ブドウ球菌 & $8.0 \times 10^{7}$ & $<10$ & $<10$ & $<10$ \\
\hline クロコウジカビ & $4.0 \times 10^{3}$ & $6.0 \times 10$ & $<10$ & $<10$ \\
\hline
\end{tabular}

\begin{tabular}{|l|c|c|c|c|}
\hline $\begin{array}{l}\text { プロピルパラベン }(0.1 \%) \\
+ \text { ポリソルベート } 80(1 \%)\end{array}$ & 初期值 & 7 日目 & 14 日目 & 21 日目 \\
\hline 大腸菌 & $2.0 \times 10^{7}$ & $6.1 \times 10^{2}$ & $<10$ & $<10$ \\
\hline 黄色ブドウ球菌 & $7.5 \times 10^{7}$ & $6.0 \times 10^{4}$ & $2.6 \times 10^{3}$ & $<10$ \\
\hline クロコウジカビ & $4.9 \times 10^{5}$ & $2.2 \times 10^{5}$ & $2.1 \times 10^{5}$ & $1.6 \times 10^{5}$ \\
\hline
\end{tabular}

\begin{tabular}{|l|c|c|c|c|}
\hline $\begin{array}{l}\text { プロピルパラベン }(0.1 \%) \\
+\mathrm{PEG}-60 \text { 水添シマシ油 }(1 \%)\end{array}$ & 初期值 & 7 日目 & 14 日目 & 21 日目 \\
\hline 大腸菌 & $2.0 \times 10^{7}$ & $1.4 \times 10^{5}$ & $6.1 \times 10^{3}$ & $3.3 \times 10^{3}$ \\
\hline 黄色ブドウ球菌 & $7.5 \times 10^{7}$ & $2.6 \times 10^{6}$ & $5.1 \times 10^{5}$ & $3.4 \times 10^{4}$ \\
\hline クロコウジカビ & $4.9 \times 10^{5}$ & $1.4 \times 10^{5}$ & $6.0 \times 10^{4}$ & $2.4 \times 10^{5}$ \\
\hline
\end{tabular}


る ${ }^{12,13)}$ が，これら共存成分の影響も $\mathrm{POE}$ 系界面活性 剤と比べ，PGFEは影響が小さい傾向となることを確認 している ${ }^{14)}$ 。

つまり, Fig. 3 の現象は, POE系非イオン界面活性剂 は温度上昇や他共存成分によって親水性から親油性へと 移行したが，PGFEはそれらの影響が少なく，親油性へ と移行し難かったためと考えることができる。

\section{$3 \cdot 2$ 両連続型マイクロエマルションや水の可溶化}

PGFEを用いた両連続型マイクロエマルションの例と しては, 特定の PGFE を用いて結晶性のある難溶性物質 を安定に且つ多量に可溶化できる事が知られている ${ }^{15)}$ そこでは，両連続構造体を更に水に希勫する事で微細な ミセルを調製し，難溶性物質の皮膚透過性を向上させる ことで, 肌の保湿性やハリといった肌状態の変化にも有 用な効果があったと報告されている。

また，オイルへの水の可溶化といった逆ミセル形成の 実用例について紹介する。2 種の PGFE を併用する事で 油性成分に多量の水を可溶化させることができるが，こ れは濡れた手でも高い洗浄力がある耐水性クレンジング オイルへの応用として報告されている ${ }^{5)}$ 。

\section{4 ポリグリセリン脂肪酸エステルを用いた乳化特性}

乳化とは, 均一に溶解しない二つの液体の一方が他の 液体中に微細な液滴となって分散した系であり，生成物 を乳化物（エマルション）と呼び, $\mathrm{O} / \mathrm{W}$ 型，W/O 型な ど様々な種類がある。乳化物は本質的に不安定であり, 時間の経過と共にその状態は変化し, 最終的には分離す る性質を有する。このような性質を有することから，乳 化物は熱力学的に非平衡（不安定）な系であると定義さ れ，熱力学的平衡（安定）系である可溶化とは全く異な る。一般的に乳化の型は界面活性剂の HLBにより決定 され，HLB 值の高いものは $\mathrm{O} / \mathrm{W}$ 型，低いものは $\mathrm{W} / \mathrm{O}$ 型の調製に適しているが，これは一次的な選択の指標に 過ぎず，実際には油の種類や界面活性剂の溶存挙動を変 化させるような成分の添加などにより，選択すべき界面 活性剤は異なってくる。 $\mathrm{O} / \mathrm{W}$ 乳化については, 親水性 乳化剤と親油性乳化剂を組み合わせた混合 HLB が，油 の所用 HLB と同じになることで，安定な乳化物が得ら れることが知られている16)。

乳化物の崩壊は, クリーミング・凝集・合一という素 過程を経て進行する。クリーミングを防止するためには 界面活性剤の種類や乳化方法を最適化して乳化物の液滴 の大きさを微細化することが，凝集を防止するためには 液滴表面の表面電位を大きくして静電斥力を働かせるこ とが有効である。一方で，合一を防止するためには，界 面活性剤を最適化して油水界面の界面張力を最小にする
だけでなく，界面膜を強固にすることが望ましい。乳化 処理の方法としては, 大きく分けて攪拌・ せん断などの 強力な機械力を利用した物理的方法, ならびに界面活性 剂の特性を活かした化学的方法に大別され，乳化におい てはこれらのバランスを考慮することが重要である。

乳化の化学的方法は幾つか報告されており，O/W 型 では転相温度 (PIT) 乳化法や転相 (PIC) 乳化法, D 相乳化法, 液晶乳化法, $\alpha$ ゲル乳化法などが, W/O 型 では粘土鉱物を利用した方法や，アミノ酸ゲル乳化法な どの様々な乳化方法が知られている。

PIT 乳化法は, 乳化物の安定化に大きく寄与する微細 な乳化物の調製方法として知られ，POE系界面活性剂 のHLBの温度依存性を巧みに利用した方法である。 PIT より高い温度では W/O 型に, PIT 近傍では界面活 性剂吸着相の平均曲率がゼロとなる D 相の状態となり, このときの油水界面の界面張力もほぼゼロとなるため, 攪拌によって極めて微細な乳化物を調製することができ る。ただし，この乳化物は不安定であり，時間の経過と ともに急速に合一するため，急冷する事で，安定な O/ $\mathrm{W}$ 型の乳化物となる ${ }^{17)}$ 。

\section{4・1 PGFEの特徵を活かした乳化法}

PGFE は, 温度による HLB の変化が小さく, 転相温 度が出現する HLBの範囲も狭いため, PIT 乳化法は適 さないと考えられる。ここでは, PGFEの界面活性剤の 自己組織体を形成しやすいという特徵（水，油ともに CMC が低く疎媒性がある) $)^{18)}$ を活かした PIC 乳化によ る微細な乳化物調製の例を紹介する ${ }^{19)}$ 。エステル化度 が異なる各種オレイン酸デカグリセリル (5\%)を油相 (エ チルヘキサン酸セチル）に添加溶解し，プロペラ擋拌下 で水相を徐々に加えて乳化し, 擋挥冷却して $\mathrm{O} / \mathrm{W}$ 型乳 化物を調製した結果, ジエステル体を中心にその前後の 範囲では乳化粒子径の小さい乳化物を得た。そこで, 乳 化過程における溶存状態の変化を調べるために疑似 3 成 分系の相図を作成した（Fig. 4)。20wt％の各種オレイ ン酸デカグリセリルを含んだエチルヘキサン酸セチル中 （A-B 軸上）に水を添加して行った時（頂点 C 方向）の 溶存状態の変化を見ている。乳化粒子径の細かい乳化物 が生成する範囲においては, 水の添加に伴い可溶化（逆 ミセル油溶液）相, 液晶相, O/D ゲル相を経て O/W 型 乳化物を形成している。このような油水界面張力が低く なる状態を経ているため, 乳化粒子径が細かくなったも のと考えられる。従って, PIC乳化法はPGFEを用い た乳化物の調製には適していると考えられる。エチルへ キサン酸セチル以外の油でも, 流動パラフィンなど極性 の低い油も同様に微細な乳化物の調製が可能であるが, 極性の高いシリコーンオイルなどでは, 微細な乳化物を 


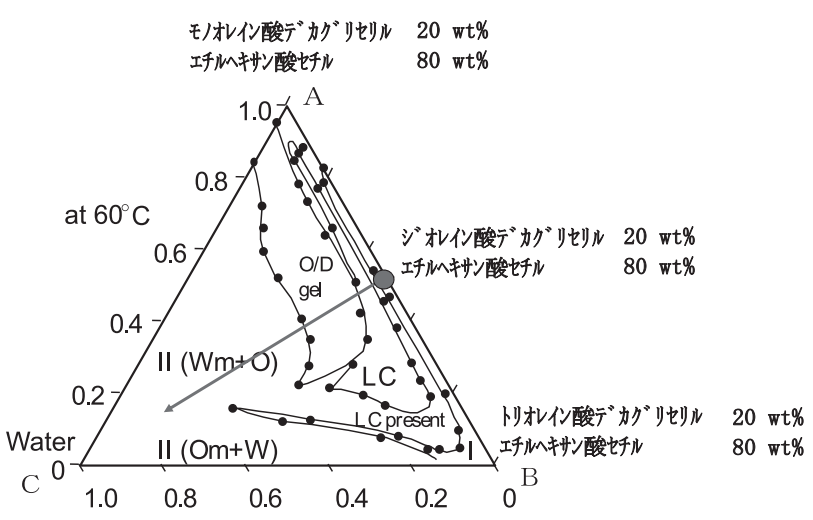

Fig. 4 擬似 3 成分相図による乳化過程の検討 ${ }^{19)}$

調製することはできない。また, PGFE を用いた乳化は, 先の可溶化でも紹介した通り，共存成分や温度による影 響を受けにくい為，耐塩や耐熱性がある乳化物を調製す ることができる。

PGFE を用いた D 相乳化は, 親水性の高い PGFE を 多価アルコール水溶液に溶解させ, そこに徐々に油相を 添加していき, 高粘性の透明なゲルエマルションを調製 し ${ }^{4)}$ ，これを水で希䣋することで微細な乳化物を得るこ とができる。このゲルエマルションは, 化粧品分野にて O/D 型のクレンジングジェルとして利用でき，また希 釈した乳化物は乳液や入浴剤などで利用されている。

また，油水界面の界面膜の弾性を高めることによって 液滴の合一を防止できる $\alpha$ ゲル乳化法は, 陽イオン性 界面活性剂と高級アルコールを用いた方法が一般的に知 られているが, PGFEを用いても $\alpha$ ゲル乳化をするこ とができる。

$\alpha$ ゲルとは, ラメラゲル相が複雑に絡み合ったゲル ネットワーク構造を成し, その結果エマルションを安定 化させている, 複数相から成るコロイド形態である。ラ メラ相中の $\alpha$ ゲルは, 六方晶に配列された結晶構造を 形成し, 原料由来の結晶とは異なる融点を持つ半透明な 半結晶体であり，六方晶を形成する分子のアルキル鎖は 全ての結合がトランス配位となっている。そのため, $\alpha$ ゲルの二重膜は, ラメラ液晶の二重膜と比較すると界面 膜強度は約 4 倍になるといわれており, これが液滴の合 一防止に大きな効果を発揮している。 $\alpha$ ゲルは, $\alpha$ 結晶 とは根本的に異なり, 各アルキル鎖が軸を中心に回転の 自由度を持つ非特異性のアルキル鎖充填状態であると考 えられており, 油を両親媒性物質のアルキル鎖側で囲ま れた液体油相として存在する為, さまざまな油を乳化さ せる事ができる事が知られている。

ここでPGFEの $\alpha$ ゲル形成確認の検討例について紹 介する。 $\alpha$ ゲル形成確認は, 外観観察, 示差走査熱量分 析 (DSC), X 線散乱測定により判断した。サンプルは,

\section{A DSC測定}

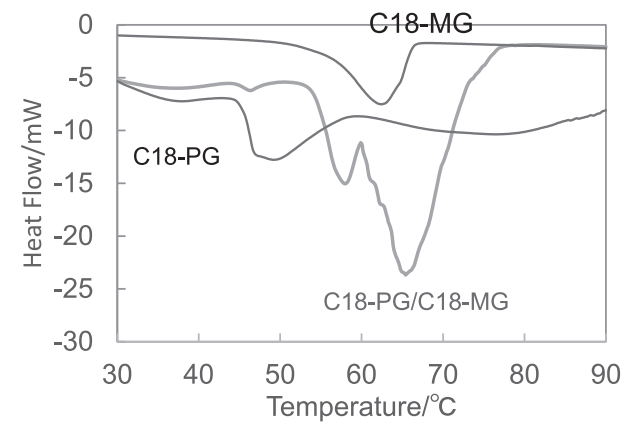

B X線散乱測定

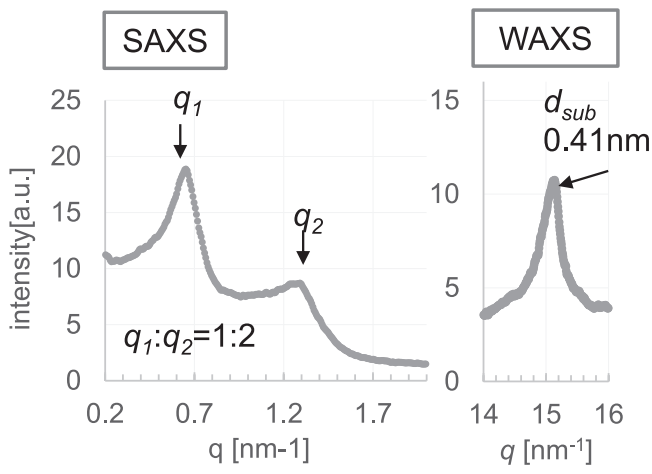

Fig. 5 ポリグリセリン脂肪酸エステルの $\alpha$ ゲル形成確認

界面活性剂 $20 \%$ と水 $80 \%$ をスリュー管に計量し, $85^{\circ} \mathrm{C}$ で加熱溶解した後 1 分間攪汼, その後放冷し調製し た。測定は, DSC 解析（株式会社リガク社製, Thermo Plus XRD-DSC II)，X 線散乱測定 (Anton Paar 社製, SAXSess camera）用いて実施した。結果, 外観は全体 が均一な白色ペースト状であり, またDSC 解析の結果 はFig. 5A の通りで, ステアリン酸ポリグリセリル（C18-

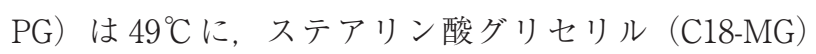
は $62^{\circ} \mathrm{C}$ に吸熱ピークが観察されたが, これらの混合製 剂はそれらとは異なる $66^{\circ} \mathrm{C} に$ 吸熱ピークが観察され た。次いで, 先の混合製剤の X 線散乱測定の結果を Fig. $5 B$ に示す。小角散乱領域に見られる鋭いピークは長周 期構造の形成を示し, ピーク比が $\mathrm{q}_{1}: \mathrm{q}_{2}=1: 2$ であっ たことからラメラ構造であることが示唆された。また, 広角領域に $\mathrm{q}$ 值 $\left.=15.1 （ \mathrm{~d}_{\mathrm{sub}}=0.41 \mathrm{~nm}\right)$ の鋭い単一ピー クが観察されたことから, 固体状態の疎水鎖が六方晶に 配列していることが示唆された。

これらの結果より, PGFEにて $\alpha$ ゲルが形成される ことが確認された。

$\alpha$ ゲルを形成する界面活性剤が油に可溶しやすいもの は $\alpha$ ゲル構造の崩壊につながると考えられるが PGFE は水中, 油中共に単分散飽和溶解度が低く, 低濃度から 界面活性能を発揮するため $\alpha$ ゲル構造を形成しやすい だけでなく, 経時安定性に優れるという特徵がある ${ }^{20)} 。$ 
$\alpha$ ゲル乳化物は, ラメラ構造由来の保湿性だけでなく, さまざまな利点がある。 $\alpha$ ゲルは静置状態において，粘 性よりも弾性を強く発現し, 明瞭な降伏点があり，せん 断により強い粘度低下を示す為, 伸びの良い乳化物が調 製できる。また， $\alpha$ ゲル構造体が少量であっても，これ ら物質は一般的に使用される $\mathrm{O} / \mathrm{W}$ 型界面活性剂と比較 すると，より大きく親油性である。したがって，これら $\alpha$ ゲル乳化物は皮膚表面への付着性が高く，塗布膜の持 続性も期待できる。

他, PGFE は W/O 型乳化物の調製にも良く利用され, 特に乳化力の高い縮合リシノレイン酸ポリグリセリル は，高内相比乳化できる素材として知られている。分散 相容積の大きな乳化物の調製も応用価值の高い技術であ り，食品分野においては低脂肪 $\mathrm{W} / \mathrm{O}$ クリームとして, 化粧品分野では高内水相を活用し，油性感が無くさっぱ りとした感触で汗でも流れない等の耐水性や持続性を付 与させた $\mathrm{W} / \mathrm{O}$ 型リキッドファンデーションなどで利用 されている。

\section{5 おわりに}

本稿では, PGFEの可溶化・乳化特性について, PGFEの特徵を活かした実例をもとに紹介した。PGFE は可溶化・乳化といった機能以外にも様々な界面科学的 な機能を有しており，幅広く利用されている。また，低 刺激で保湿性も高く，なめらかで心地よい肌感触を演出 する素材として大変興味深い素材である。近年では，植 物由来の素材であり，生分解性を有する PGFE は，環 境に優しい素材としても注目されている。今後も安心・ 安全で環境に優しい素材の応用技術を追求して利用価值 を高めていくことは原料メーカーの責務であると考えて いる。本稿が，みなさまの研究・製品開発の一助になれ ば幸いである。

\section{文 献}

1）加藤友治，食品化工技術， 19，81-90（1999）. (Kato, T. J. Jpn. Soc. Food Eng. 19, 81 (1999))

2) 内田一仁, 高瀨嘉彦, Fragrance Journal 30 (6), 129134 (2002).

(Uchida, K.; Takase, Y. Fragrance J. 30 (6), 129 (2002))

3）樋口智則, 渡邊充, 福原寛央, Fragrance Journal 45 (3), $58-62(2017)$

(Higuchi, T.; Watanabe, M.; Fukuhara, H. Fragrance J. $45(3), 58(2017))$

4) 岩永哲朗, 内田一仁, Fragrance Journal 31 (12), 106-112 (2003)
(Iwanaga, T.; Uchida, K. Fragrance J. 31 (12), 106 (2003))

5）岩永哲朗, 内田一仁, 竹内伸之, 阿部能久, J. Soc. Cosmet. Jpn. 39, 186-194 (2005).

(Iwanaga, T. : Uchida, K.; Takeuchi, N.; Abe, T. J. Soc. Cosmet. Jpn. 39, 186 (2005))

6) Kamata, M. et al. J. Soc. Cosmet. Chem. Jpn. 46, 93100 (2012).

7）松下和男, 塩山浩, ポリグリセリン脂肪酸エステルの 現状, 油化学 35, 71-79（1986）。

(Matsushita, K.; Shioyama, H. J. Jpn. Oil Chem. Soc. 35, 71 (1986)

8）坂本一民ら“『化粧品科学へのいざない』シリーズ 第 2 巻”, 薬事日報社, p.120 (2018).

(Invitation to Cosmetrogy [2]. Sakamoto, K. et al. eds. Yakuji Nipposha Co. Ltd., (2018))

9) 特許 4099112 (Japan Pat. 4099112)

10) Karlstrom, G. J. Phys. Chem. 89, 4962-4964 (1985).

11) Kunieda, H.; Akahane, A.; Feng, J.; Ishitobi, M. J. Colloid Interface Sci. 245, 365-370 (2002).

12) Iwanaga, T.; Kunieda, H. J. Colloid Interface Sci. 227, 349-355 (2000)

13）鷺谷広道, 池田由美子, 大郷保治, 油化学 33, 156161 (1984).

(Sagitani, H.; Ikeda, Y.; Osato, Y. J. Jpn. Oil Chem. Soc. 33, 156 (1986))

14）熊澤史貴, 高橋宏輝, 川合丈志, 第 53 回日本油化学会 年会 発表講演要旨集 2E-17（2014）。

(Kumazawa, F. et al. The $53^{\text {th }}$ Annual Meeting of the Japan Oil Chemists' Society, Sapporo, Abstract 2E-17 (2014))

15) Fukuhara, H. et al. J. Soc. Cosmet. Chem. Jpn. 42, 297304 (2008)

16) The HLB System. ICI Americans Inc., Wilmington, Delaware p. 19 (1984).

17) Kunieda, H.; Shinoda, K. J. Colloid Interface Sci. 107, 107-136 (1985)

18) Hashimoto, S. et al. Material Technology 20, 255-261 (2002)

19）岩永哲郎，高橋宏輝，新・化粧品開発のための美容理論, 処方 / 製剂, 機能評価の実際 第 5 章, 技術教育出版, pp.76-86 (2014).

(Iwanaga, T. et al. in Beauty Theory and Recipe for Cosmetics. Chap. 5. Gijutsukyoikushuppan Co. Ltd., Tokyo (2014))

20）山下裕司, 樋口智則, 平尾哲二, 最新 - 化粧品開発の ための美容理論, 処方 / 製剂, 機能評価の実際 第 36 章, 技術教育出版, pp. 392-403 (2014).

(Yamashita, Y. et al. in Beauty Theory and Recipe for Cosmetics. Chap. 36. Gijutsukyoikushuppan Co. Ltd., Tokyo (2014)) 